\title{
Vibration Reduction of an Existing Glass Window through a Viscoelastic Material-Based Retrofit
}

\author{
Qian Feng ${ }^{1,2}$, Liming Fan ${ }^{3, \dagger}$, Linsheng Huo ${ }^{3, *(1)}$ and Gangbing Song $4, *$ (1) \\ 1 Key Laboratory of Earthquake Geodesy, Institute of Seismology, China Earthquake Administration, \\ Wuhan 430071, China; fengqian@eqhb.gov.cn \\ 2 Wuhan Institute of Earthquake Engineering, Wuhan 430071, China \\ 3 State Key Laboratory of Coastal and Offshore Engineering, Dalian University of Technology, Dalian 116024, \\ China; fanliming421@126.com \\ 4 Department of Mechanical Engineering, University of Houston, 4800 Calhoun, Houston, TX 77204, USA \\ * Correspondence: lshuo@dlut.edu.cn (L.H.); gsong@uh.edu (G.S.) \\ + The co-first author due to his equal contribution with the first author.
}

Received: 13 June 2018; Accepted: 28 June 2018; Published: 29 June 2018

\begin{abstract}
The damping properties of glass windows have a great influence on the comfort of the occupants, especially for buildings that are close to a vibration source, such as rail tracks. With the increasing popularity of light rails in cities, there is a strong need to retrofit existing glass windows to improve their damping properties, and increase the occupants' comfort. In this paper, a new method of retrofitting existing glass windows for vibration reduction was developed using viscoelastic treatment. The key component of the retrofit was a self-adhesive glass constrained viscoelastic strip (SaGCVS), consisting of a thin glass constraining layer, a viscoelastic layer, and an adhesive layer. The SaGCVSs can be easily bonded onto an existing glass panel near its edge in an effort to improve its inherent damping properties, and to reduce its vibration when subjected to external excitations. The method is simple, and the proposed viscoelastic strip is easy to install. Experiments were carried out to demonstrate the effectiveness of the proposed method. For the vibration measurements, lead zirconate titanate (PZT) patches were mounted onto the four corners and the center of the window glass panel. Comparative studies were performed, and the results clearly showed that the vibration of the window glass panel was reduced, revealing the effectiveness of the proposed retrofitting method for improvement in the damping properties of existing window structures.
\end{abstract}

Keywords: window glass; retrofit for damping improvement; vibration reduction; viscoelastic materials; lead zirconate titanate (PZT); constrained viscoelastic layer

\section{Introduction}

Windows, the interface between the indoor and outdoor environments, play highly important roles in creating comfort for residents. A glass window has important functions, such as allowing natural lighting, providing thermal insulation, and providing sound isolation [1]. Since the damping ratio of a window glass panel is relatively low, when subjected to mechanical excitations, such as those induced by a passing train [2], window glass often generates considerable noise, lowering residential comfort. In some cases, large vibrations can even result in broken glass and the injury of people.

Over the past several decades, research on the vibration control of civil structures and mechanical systems attracted much attention. Various control methods were developed and implemented to attenuate vibration [3]. Tuned mass dampers (TMDs) [4], which are effective and reliable for suppressing undesirable vibrations induced by winds and earthquake loads, were extensively utilized in tall buildings and towers. Recently, pounding-tuned mass dampers [5-7] and eddy-current-tuned 
mass dampers $[8,9]$ were proposed for structural vibration control. As a passive device, particle dampers were studied for the vibration control of various systems [10-13]. In addition, vibration isolation was researched for structural vibration reduction [14-16].

In recent years, semi-active devices received attention for vibration control. Semi-stiffness control devices were adopted to control the stiffness of structures in an effort to establish a non-resonant condition during earthquakes [17,18]. Electrorheological (ER) dampers [19-21] with controllable damping forces were reported for the vibration control of civil structures. Magnetorheological (MR) dampers [22-27] are essentially the magnetic equivalent of ER dampers, where the control effect is governed by a magnetic field, instead of an electric field. With much larger control forces, MR fluid dampers were applied in structural vibration control [28-30].

Due to their advantages regarding efficient energy dissipation, viscous dampers [31-36] were widely utilized in civil structures to control seismic, wind-induced, and thermally induced vibration. In addition, viscoelastic damping materials found many applications in automobile and aerospace structures [37]. Viscoelastic dampers (VEDs) were demonstrated as effective in providing structures with considerable damping to reduce vibration due to wind-induced, seismic, and other excitations [38-44]. However, all these devices are mechanical systems with many parts, and they are not suitable for glass window panels due to their aesthetic, weight, and dimension requirements.

For the vibration reduction of a glass window, the damper should be lightweight, and have a minimal dimension intrusion, and aesthetic appeal. For the vibration reduction of a glass panel, there are few reported papers and patents. Kasparek [45] used an experimental set-up consisting of microphones and a two-dimensional (2D) vibrometer to measure local amplitudes and phases of out-of-plane glass motion, in which the vibration and noise transfer characteristics were measured. Various methods that can help improve the damping of a glass window are listed below.

1. The use of both air-film damping technology and viscoelastic material. Lewis and Parin developed a window damping system that employs both air-film damping technology and viscoelastic damping materials to improve mechanical and/or acoustic vibration damping in window structures [46].

2. The use of laminates with a viscoelastic layer. Krois et al. [47] proposed an experiment showing that the use of a two-phase adhesive applied via a co-extrusion method with a low-viscosity core can dramatically lower the overall level of vibrations in window glass by $30-50$ percent, and in particular, can bring about a flattening of the resonance peaks in the all-important roll vibration range between $100 \mathrm{~Hz}$ and $500 \mathrm{~Hz}$. Bagaev et al. [48] found that multilayer window glass structures with polymer materials in a transient state reduced the amplitude of vibration of window glass. Fan et al. [49] experimentally verified the effects of vibration and noise reduction of laminated viscoelastic materials for the windows of railway vehicles. Other reported methods of increasing window damping through laminates include References [50-53]. Please note that this type of method applies to the manufacturing of new windows.

3. Improve the damping between the glass and the window frame. The viscoelastic treatment of the interface between the window glass and the window frame was also reported [54,55]. Please note that this method only applies to new windows or the installation of new windows.

Table 1 summarizes the reported technologies and solutions for the improvement of window damping. Please note that all these methods are for new windows or for installation of new windows. In addition, advances in material technology, along with newer and more efficient analytical, numerical, and experimental tools, led to damping treatments of various structures with viscoelastic materials for vibration and noise reduction [56-62]. However, all these methods are for new structures, and are not applicable to retrofitting the already installed windows for damping improvements. Other related studies [63-65] analyzed the behaviors of window glass when subjected to various excitations, including earthquakes. Window glass, which has low damping properties, experiences induced vibration and emits noise; however, retrofitting existing glass windows for vibration reduction is rarely 
studied, to the best knowledge of the authors. With the increasing popularity of light rails in cities, there is a strong need to retrofit existing glass windows in an effort to improve its damping properties, and to increase occupants' comfort.

Table 1. Pros and cons of the current solutions for increasing window damping.

\begin{tabular}{cccc}
\hline Solutions & Authors & Pros & Cons \\
\hline $\begin{array}{c}\text { Employing both air-film } \\
\text { damping technology and } \\
\text { viscoelastic damping materials }\end{array}$ & Lewis et al. [46] & $\begin{array}{c}\text { Extensive applications; } \\
\text { better vibro-acoustic } \\
\text { damping properties; } \\
\text { good optical quality. }\end{array}$ & $\begin{array}{c}\text { Damping materials integrated } \\
\text { during fabrication; not } \\
\text { suitable for retrofitting } \\
\text { existing windows. }\end{array}$ \\
\hline $\begin{array}{c}\text { Utilizing laminates or } \\
\text { multilayer technology to } \\
\text { improve the vibration } \\
\text { damping of window glass }\end{array}$ & $\begin{array}{c}\text { Krois et al. [47]; } \\
\text { Bagaev et al. [48]; } \\
\text { Farrett et al. [51]; } \\
\text { Landin et al. [52]; } \\
\text { Rehfeld et al. [53] }\end{array}$ & $\begin{array}{c}\text { Increased resistance to } \\
\text { vibratory load; better } \\
\text { vibro-acoustic damping } \\
\text { properties. }\end{array}$ & $\begin{array}{c}\text { Damping materials integrated } \\
\text { during fabrication; not } \\
\text { suitable for retrofitting } \\
\text { existing windows. }\end{array}$ \\
$\begin{array}{c}\text { Increasing the damping } \\
\text { between the glass and the } \\
\text { window frame }\end{array}$ & Kroiss M et al. [54]; & $\begin{array}{c}\text { Good design flexibility; } \\
\text { sufficient damping; } \\
\text { efficient. }\end{array}$ & $\begin{array}{c}\text { Damping materials integrated } \\
\text { during fabrication or the } \\
\text { installation process; not } \\
\text { suitable for retrofitting } \\
\text { existing windows. }\end{array}$ \\
\hline
\end{tabular}

In this paper, a new method, which is simple and effective, was developed for the retrofitting of an existing glass window in an effort to improve its damping properties. The key component of the retrofit was a self-adhesive glass constrained viscoelastic strip (SaGCVS), consisting of a thin glass constraining layer, a constrained viscoelastic layer, and an adhesive layer. The SaGCVSs were taped along the edges of an existing window glass panel to improve its damping properties. To measure the vibration response of the window glass panel, lead zirconate titanate (PZT) patches were mounted onto the four corners and the center of the window glass, and the vibration damping effect of the proposed method was evaluated. The proposed method is simple and convenient to implement, and is effective in the reduction of induced vibration. In addition, the constrained viscoelastic layer requires almost no maintenance during its service.

\section{Proposed Method and Experimental Set-Up}

\subsection{Vibration Damping Enhancement through Constrained Viscoelastic Materials}

Recently, viscoelastic materials, which possess viscoelasticity defined as a material response that exhibits the characteristics of both a viscous fluid and an elastic solid, received great attention in civil engineering [66,67]. A viscoelastic material combines elastic and viscous properties, returning to its original shape following stress; however, it does so slowly enough to oppose the next cycle of vibration. A recent research revealed that a viscoelastic material also has a good fatigue life, even when subjected to impact loads [68]. Viscoelastic materials used in engineering have two main types of structure, namely the free damping structure and the constrained damping structure [69]. When the base structure is deflected upon bending, the viscoelastic material deforms primarily in the extension and compression in the planes parallel to the base structure. The hysteresis loop of the cyclic stress and strain dissipates the energy. The constrained-layer damping treatment consists of a sandwich of two outer elastic layers with a viscoelastic material as the core [70]. When the base structure undergoes a bending vibration, the viscoelastic material is forced to exhibit shearing deformation due to the stiffness of the upper layer. Constrained-layer damping is more effective than the free-layer design since more energy is consumed and dissipated into heat during the work done by the shearing mode within the viscoelastic layer.

In this paper, a new method based on constrained-layer damping was developed to reduce the vibration of an existing glass window using a viscoelastic material. The key component for 
the retrofitting of an existing glass window was a self-adhesive glass constrained viscoelastic strip (SaGCVS). As shown in Figure 1, four such strips were mounted onto the four edges of an existing window after the surface of the glass was cleaned. A self-adhesive glass constrained viscoelastic strip, as shown in Figure 1, consists of three layers: the constraining glass layer, the constrained viscoelastic layer, and the adhesive layer. The constraining glass layer is a strip of 5-mm-thick glass, which is rigid. The constrained viscoelastic layer consists of the viscoelastic material, which is soft and flexible. The constraining glass layer is pre-bonded with the viscoelastic layer, and offers constraint to the viscoelastic layer, improving its damping capacity. The other side of the viscoelastic layer is coated with the adhesive material for easy mounting onto an existing window. In this configuration, constrained-layer damping, consisting of a sandwich of two outer elastic glass layers with a viscoelastic material as the core, was formed to improve the damping of an existing window glass. A limitation of the proposed method is that it only applies to the retrofitting of an existing glass window.

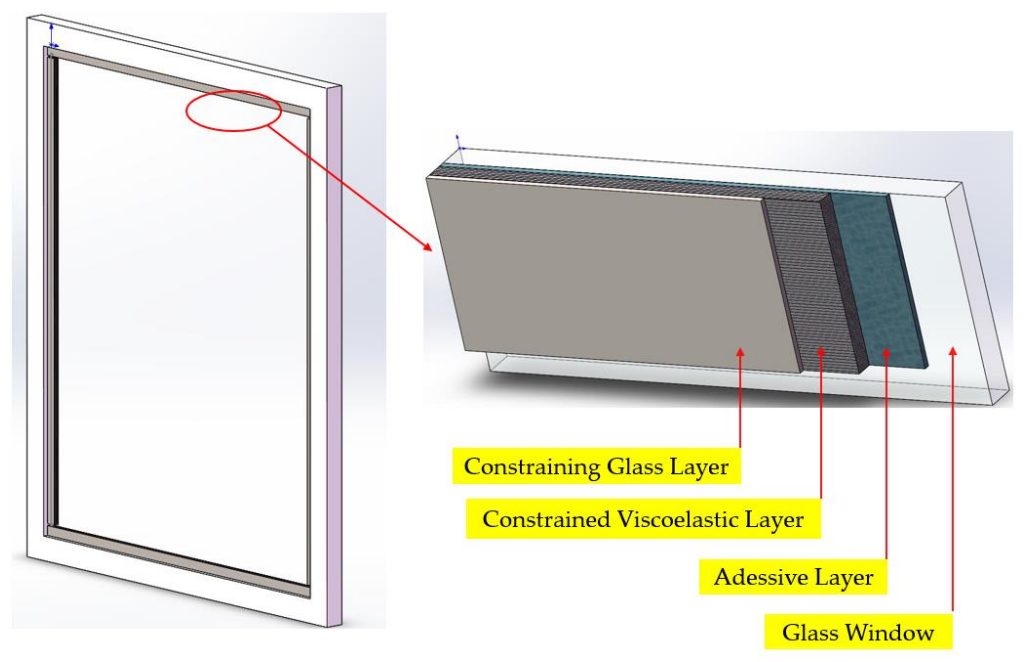

Figure 1. Illustration of the self-adhesive glass constrained viscoelastic strip (SaGCVS) for retrofitting an existing glass window.

Among various viscoelastic materials, the ZN (a butyl rubber damping material) series of damping materials is especially suitable for use as the damping layer since it can be directly bonded onto any complex geometrical surface with adhesives. Furthermore, this type of viscoelastic material has excellent durability [71,72]. In this paper, ZN22 was adopted to reduce the vibration of window glass panel, and the parameters of the viscoelastic materials are given in Table 2. A photo of a glass window with the constrained viscoelastic treatment is shown in Figure 2. In summary, the retrofitting method using the SaGCVS has the advantages of being lightweight, and having minimal dimension intrusion, and aesthetic appeal.

Table 2. Properties of the viscoelastic materials.

\begin{tabular}{ccc}
\hline & Tensile Strength $(\mathrm{MPa})$ & 15 \\
& Elongation $(\%)$ & 400 \\
Physical Property & Permanent Deformation $(\%)$ & 18 \\
& Hardness (Shore A) & 72 \\
& $70{ }^{\circ} \mathrm{C} \times 72 \mathrm{~h}$ Aging Coefficient & 1.09 \\
Specific Gravity $\left(\mathrm{g} / \mathrm{cm}^{3}\right)$ & 1.27 \\
\hline
\end{tabular}


Table 2. Cont.

\begin{tabular}{ccc}
\hline & $\beta \max$ & 1.4 \\
Damping Property & $\mathrm{T} \beta \max \left({ }^{\circ} \mathrm{C}\right)$ & 25 \\
& $\mathrm{E} \beta \max (\mathrm{N} / \mathrm{m})$ & $5 \times 10^{7}$ \\
$\Delta \mathrm{t} \beta \max =0.7\left({ }^{\circ} \mathrm{C}\right)$ & $0-50$ \\
$\Delta \mathrm{E} \beta \max =0.7(\mathrm{~N} / \mathrm{m})$ & $10^{7}-10^{8}$ \\
\hline
\end{tabular}

Note: $\beta \max$ refers to the maximum damping coefficient; $\mathrm{T} \beta \max \left({ }^{\circ} \mathrm{C}\right)$ refers to the temperature corresponding to the maximum damping coefficient; $\mathrm{E} \beta \max (\mathrm{N} / \mathrm{m})$ refers to the shear modulus corresponding to the maximum damping coefficient; $\Delta \mathrm{t} \beta \max =0.7\left({ }^{\circ} \mathrm{C}\right)$ refers to the temperature range corresponding to the maximum damping coefficient; $\Delta \mathrm{E} \beta \max =0.7(\mathrm{~N} / \mathrm{m})$ refers to shear modulus range corresponding to the maximum damping coefficient.

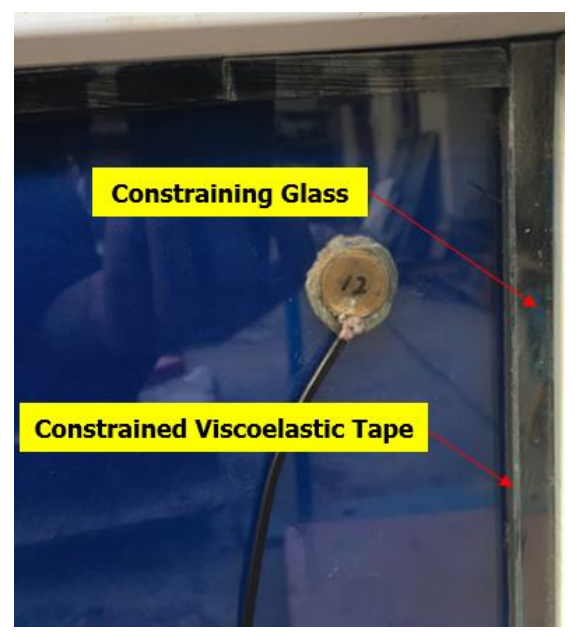

Figure 2. Detailed view of the self-adhesive glass constrained viscoelastic strip (SaGCVS): the constraining glass and the viscoelastic layer.

\subsection{Experimental Set-Up}

The dimensions of the window glass panel were $1.0 \mathrm{~m} \times 1.0 \mathrm{~m}$, and the window frame was made of plastic. Channel steel was used to restrain the four sides of the window frame in the experiment. A motor was fixed on the bottom of the channel steel to simulate the external excitations, and the axis of the motor was perpendicular to the window glass surface. Technical parameters of this excitation motor are shown in Table 3, and the excitation force for each level is shown in Table 4.

Table 3. Parameters of the vibration motor.

\begin{tabular}{ccccc}
\hline Voltage (V) & Power $(\mathbf{W})$ & Rotation Speed & Motor Control & Frequency Range (Hz) \\
\hline 220 & 30 & $0-3000 \mathrm{r} / \mathrm{min}$ & Level 1-Level 10 & $0-50$ \\
\hline
\end{tabular}

Table 4. Excitation force for each level of the vibration motor.

\begin{tabular}{ccccccccccc}
\hline Levels & $\mathbf{1}$ & $\mathbf{2}$ & $\mathbf{3}$ & $\mathbf{4}$ & $\mathbf{5}$ & $\mathbf{6}$ & $\mathbf{7}$ & $\mathbf{8}$ & $\mathbf{9}$ & $\mathbf{1 0}$ \\
\hline Excitation Force $(\mathrm{N})$ & 3.5 & 14.0 & 31.5 & 56.0 & 87.5 & 126.0 & 171.5 & 224.0 & 283.5 & 350.0 \\
\hline
\end{tabular}

\subsection{PZT Patches as Vibration Sensors and Instrumentation}

Piezoceramic, as an energy conversion material, has direct and inverse piezoelectric effects, and has a wide range of applications [73-76]. The direct piezoelectric effect (the sensing effect) refers to its ability to convert stress or strain energy into electric energy, and the inverse piezoelectric effect (the actuation effect) refers to its capacity to convert electric energy into stress or strain energy. In this 
work, PZT patches were adopted to sense the vibration of the window glass panel due to its strong piezoelectric effect, low cost, and ease of use [77-80]. In the experiment, the PZT d31 mode was selected to monitor the vibration of the window glass panel. To measure the vibration of the window glass panel, five PZT patches were mounted onto the surface of the four corners and center of the window glass panel. The experimental set-up of the window glass panel and the location of PZT patches are shown in Figure 3.

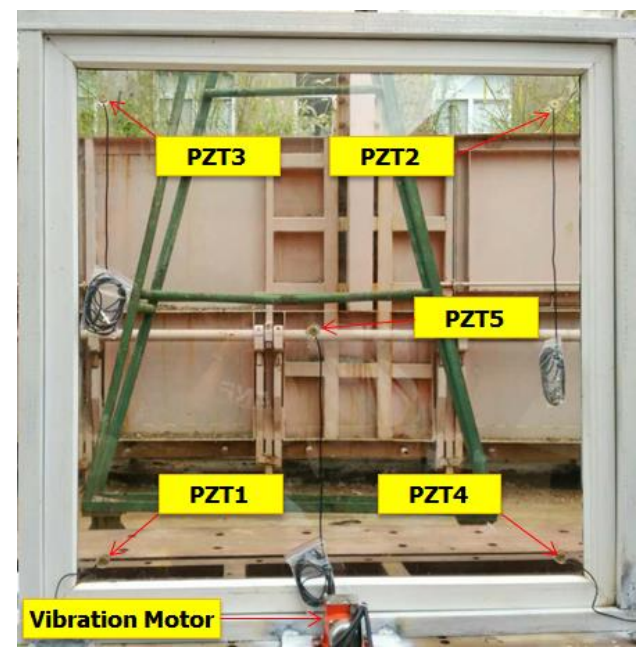

Figure 3. Experimental set-up.

The instrumentation, consisting of a data acquisition device (NI-USB 6366, National Instruments (NI), Austin, TX, USA) connected to a computer with the LabVIEW software (National Instruments (NI), Austin, TX, USA), was used to obtain the vibration history signal of the window glass panel. The instruments used in the tests are shown in Figure 4.

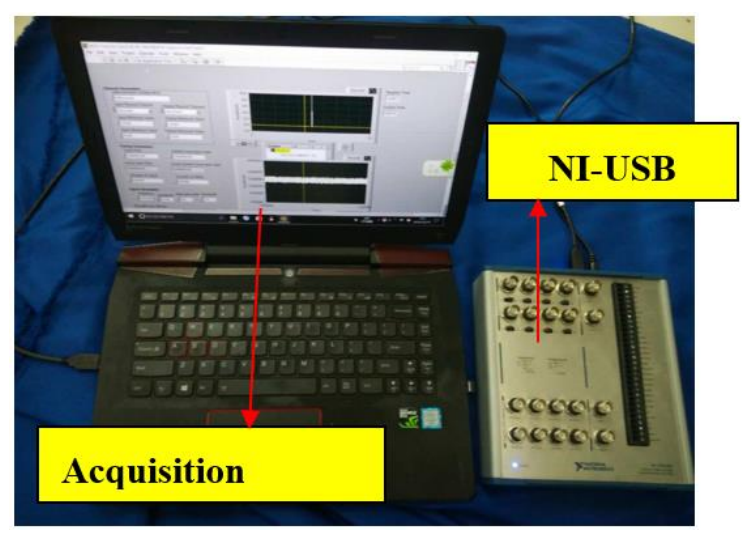

Figure 4. Instruments used in the experiment.

\section{Experimental Results and Analyses}

To study the vibration characteristics of the window glass panel, a set of experiments were performed in two cases, one without viscoelastic materials and the other with viscoelastic materials. In each case, levels 5, 7, and 9 of the motor control were used to provide vibration excitation. The excitation frequency and the amplitude of the excitation increased with each level of motor control. Two conditions were considered, one without enhancement from viscoelastic materials enhancement, and the other with enhancement from viscoelastic materials. The experimental data were collected by five PZT patches under these two conditions. The time histories of the voltage 
determined by the PZT patches are shown in Figures 5-7, and the results of the Fast Fourier Transform (FFT) amplitudes are shown in Figures 8-10.

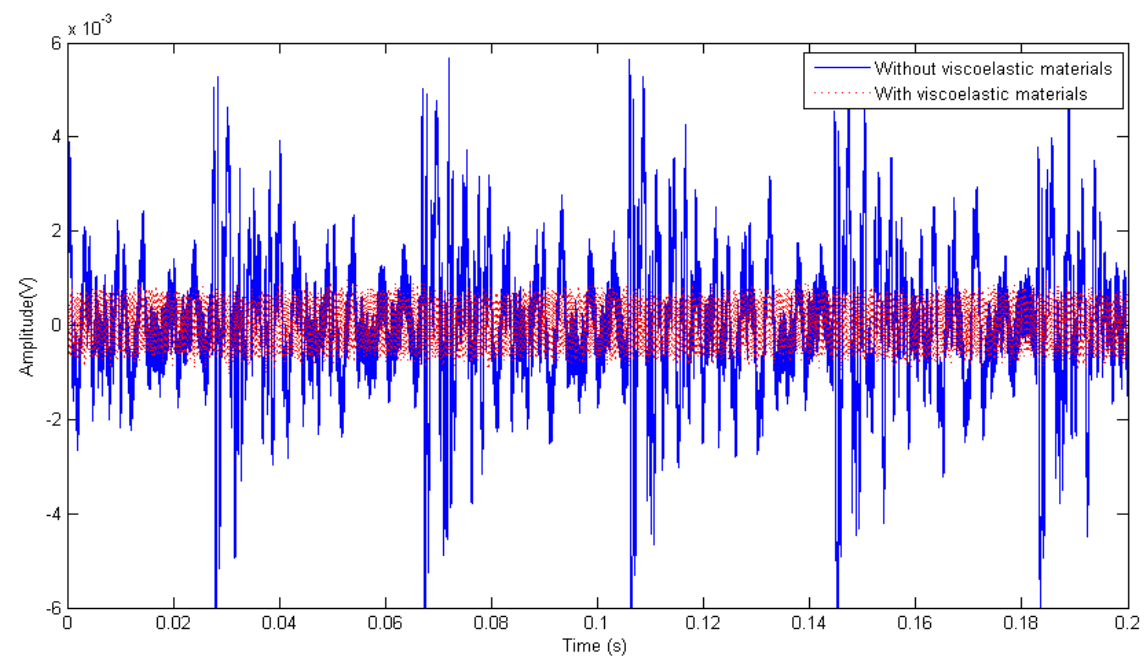

Figure 5. Time domain response curves of Lead Zirconate Titanate (PZT) 2 under level 5 conditions.

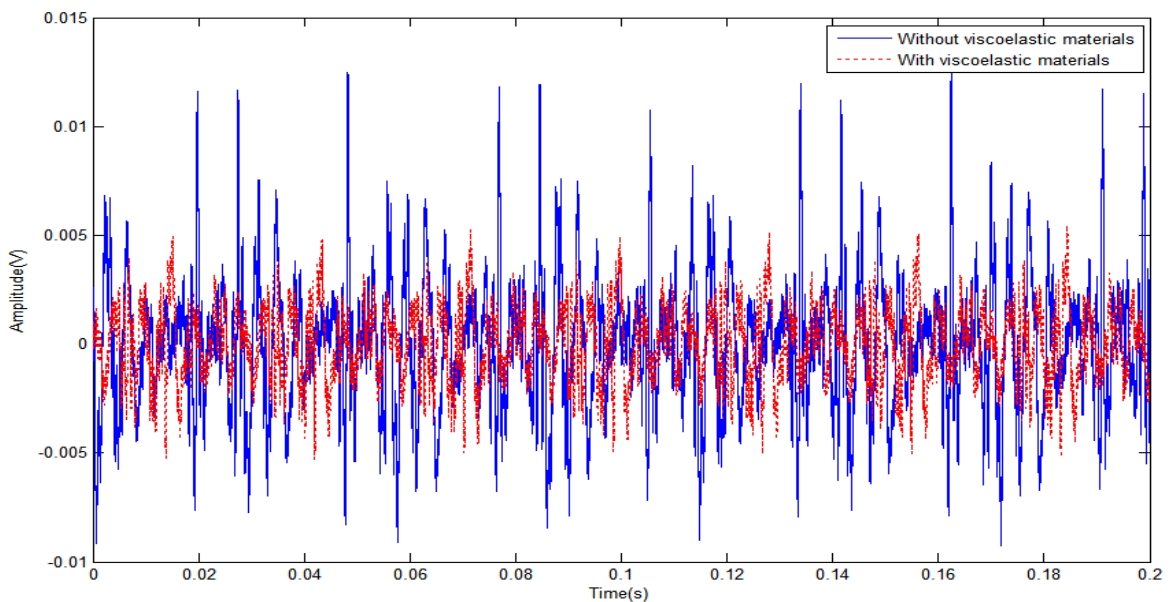

Figure 6. Time domain response curves of PZT 1 under level 7 conditions.

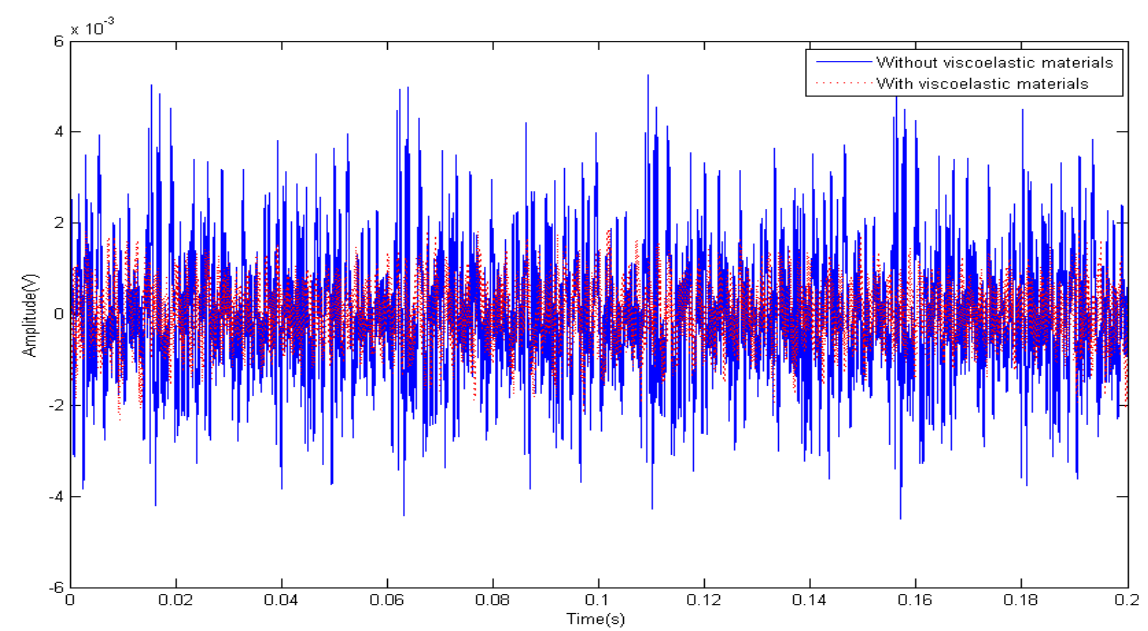

Figure 7. Time domain response curves of PZT 5 under level 9 conditions. 


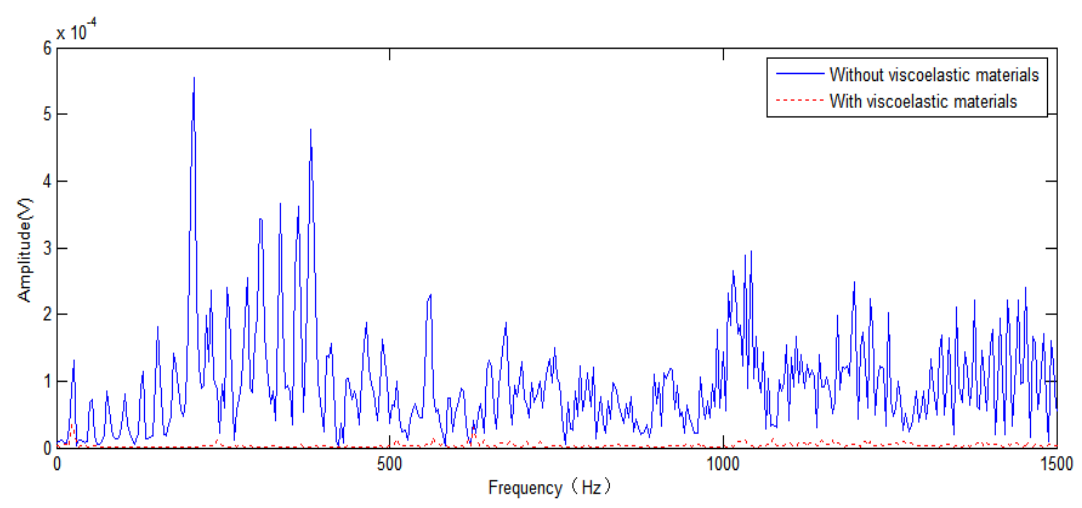

Figure 8. Frequency responses of PZT 2 under level 5 conditions.

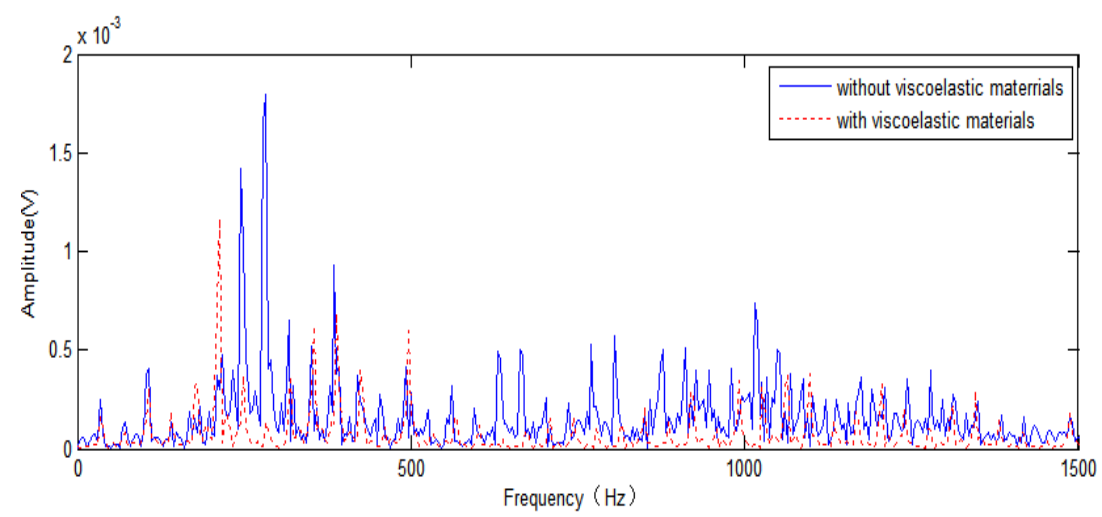

Figure 9. Frequency response curves of PZT 1 under level 7 conditions.

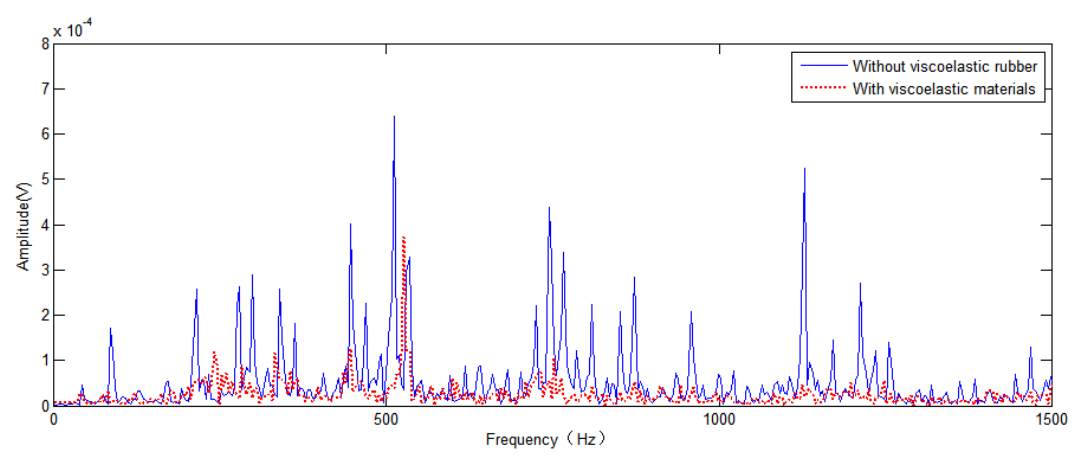

Figure 10. Frequency responses of PZT 5 under level 9 conditions.

As shown in Figures 5-10, the amplitudes of PZT patches with the viscoelastic materials were much smaller than those without viscoelastic materials. It can be summarized that the vibration of the window glass panel was suppressed by the viscoelastic materials. It should be noted that the amplitude of the voltage signal received by the PZT patches was further reduced under high excitation levels than under low excitation levels with the viscoelastic materials.

The voltage signals received by various PZT patches on the window glass panel are compared in Table 5. The table shows that the proposed retrofitting method, using the SaGCVS, increased the damping ratio of the window glass panel, with a maximum reduction in vibration of up to $66.7 \%$. The damping effect varied according to measuring point. The vibration damping effect under level 9 conditions was best, and the vibration damping effect under level 7 conditions was better than that under level 5 conditions. This can be explained by the damping mechanism of viscoelastic materials, 
where the more the severe the vibration is, the larger the hysteretic loop becomes, resulting in a larger energy dissipation. In summary, the proposed simple method of retrofitting the existing glass window using the constrained viscoelastic strip was effective.

Table 5. Reduction of the peak amplitude in Fast Fourier Transform (FFT) with various levels of vibration. VE-viscoelastic.

\begin{tabular}{|c|c|c|c|c|c|c|c|c|c|}
\hline \multirow{2}{*}{$\begin{array}{l}\text { Measuring } \\
\text { Points }\end{array}$} & \multicolumn{3}{|c|}{ Level 5 Conditions } & \multicolumn{3}{|c|}{ Level 7 Conditions } & \multicolumn{3}{|c|}{ Level 9 Conditions } \\
\hline & $\begin{array}{l}\text { Without } \\
\text { VE }\end{array}$ & With VE & $\begin{array}{l}\text { Reduction } \\
\text { Ratio (\%) }\end{array}$ & $\begin{array}{c}\text { Without } \\
\text { VE }\end{array}$ & With VE & $\begin{array}{l}\text { Reduction } \\
\text { Ratio (\%) }\end{array}$ & $\begin{array}{l}\text { Without } \\
\text { VE }\end{array}$ & With VE & $\begin{array}{l}\text { Reduction } \\
\text { Ratio (\%) }\end{array}$ \\
\hline 2 & $3.75 \times 10^{-5}$ & $3.2 \times 10^{-5}$ & 14.7 & $2.0 \times 10^{-3}$ & $1.3 \times 10^{-3}$ & 35.0 & $1.9 \times 10^{-3}$ & $1.0 \times 10^{-3}$ & 47.4 \\
\hline 3 & $4.0 \times 10^{-5}$ & $3.5 \times 10^{-5}$ & 12.5 & $3.0 \times 10^{-3}$ & $1.2 \times 10^{-3}$ & 60.0 & $1.6 \times 10^{-3}$ & $8.0 \times 10^{-4}$ & 50.0 \\
\hline 4 & $2.5 \times 10^{-5}$ & $1.2 \times 10^{-5}$ & 52.0 & $1.8 \times 10^{-3}$ & $1.3 \times 10^{-3}$ & 27.8 & $3.7 \times 10^{-3}$ & $2.0 \times 10^{-3}$ & 45.9 \\
\hline
\end{tabular}

\section{Conclusions}

In this paper, a new, simple but effective method of retrofitting an existing glass window to improve its damping properties was developed. The key component of this method was a self-adhesive glass constrained viscoelastic strip (SaGCVS), consisting of a thin glass constraining layer, a viscoelastic layer, and an adhesive layer. The SaGCVSs were bonded to the edges of the existing glass window so as to improve its damping properties, and to reduce its vibration when subjected to excitations. Lead zirconate titanate (PZT) patches were mounted onto the four corners and the center of the window glass panel to measure its vibration response. Experiments were conducted to study the damping capacity of the proposed method. The experimental results clearly demonstrated the effectiveness of the constrained viscoelastic layer in improving the damping of a glass window, and in reducing vibration. The proposed method is easy to implement, and the damping strip has aesthetic appeal. In addition, the proposed method is almost maintenance-free. The proposed method has great potential in applications to improve the damping of an existing glass window, ensuring window safety during extreme events such as earthquakes.

Author Contributions: All authors discussed and agreed upon the idea and made scientific contributions. Q.F. and G.S. conceived the original idea. G.S., L.F., and L.H. designed the experiments. L.F. and L.H. conducted the experiments, and analyzed the data. Q.F., L.F., and L.H. wrote the paper. G.S. revised the paper.

Funding: This work was partially supported by the Director Foundation of Institute of Seismology, China Earthquake Administration (Grant number IS201616250), National Natural Science Foundation of China (Grant number 51608493), Natural Science Foundation of Hubei Province (Grant number 2017CFB509). The authors would like to thank for these financial supports.

Acknowledgments: This work was partially supported by the Director Foundation of Institute of Seismology, China Earthquake Administration (Grant number IS201616250), the National Natural Science Foundation of China (grant number 51608493), and the Natural Science Foundation of Hubei Province (grant number 2017CFB509). The authors would like to thank these institutions for their financial support.

Conflicts of Interest: The authors declare no conflicts of interest in this paper.

\section{References}

1. Naqash, T.; Formisano, A.; De Matteis, G. Design and performance testing of a skylight in Qatar. Key Eng. Mater. 2016, 710, 262-267. [CrossRef]

2. Feng, Q.; Zhang, Y.; Zhu, N.; Wang, H. Design of remote real time monitoring system based on gprs for railway roadbed subsidence. J. Geod. Geodyn. 2013, 33, 155-157.

3. Song, G.; Cai, S.C.S.; Li, H.-N. Energy dissipation and vibration control: Modeling, algorithm, and devices. Appl. Sci. 2017, 7, 801. [CrossRef]

4. Rana, R.; Soong, T.T. Parametric study and simplified design of tuned mass dampers. Eng. Struct. 1998, 20, 193-204. [CrossRef] 
5. Wang, W.; Hua, X.; Wang, X.; Chen, Z.; Song, G. Numerical modeling and experimental study on a novel pounding tuned mass damper. J. Vib. Control 2017, 2. [CrossRef]

6. Tian, L.; Rong, K.; Zhang, P.; Liu, Y. Vibration control of a power transmission tower with pounding tuned mass damper under multi-component seismic excitations. Appl. Sci. 2017, 7, 477. [CrossRef]

7. Song, G.B.; Zhang, P.; Li, L.Y.; Singla, M. Vibration control of a pipeline structure using pounding tuned mass damper. J. Eng. Mech. 2016, 142, 04016031. [CrossRef]

8. Wang, W.; Dalton, D.; Hua, X.; Wang, X.; Chen, Z.; Song, G. Experimental study on vibration control of a submerged pipeline model by eddy current tuned mass damper. Appl. Sci. 2017, 7, 987. [CrossRef]

9. Chen, J.; Lu, G.; Li, Y.; Wang, T.; Wang, W.; Song, G. Experimental study on robustness of an eddy current-tuned mass damper. Appl. Sci. 2017, 7, 895. [CrossRef]

10. Papalou, A.; Masri, S.F. An Experimental investigation of particle dampers under harmonic excitation. J. Vib. Control 1998, 4, 361-379. [CrossRef]

11. Lu, Z.; Wang, D.; Zhou, Y. Experimental parametric study on wind-induced vibration control of particle tuned mass damper on a benchmark high-rise building. Struct. Des. Tall Spec. Build. 2017, 26. [CrossRef]

12. Papalou, A.; Strepelias, E.; Roubien, D.; Bousias, S.; Triantafillou, T. Seismic protection of monuments using particle dampers in multi-drum columns. Soil Dyn. Earthq. Eng. 2015, 77, 360-368. [CrossRef]

13. Lu, Z.; Chen, X.; Zhang, D.; Dai, K. Experimental and analytical study on the performance of particle tuned mass dampers under seismic excitation. Earthq. Eng. Struct. Dyn. 2017, 46, 697-714. [CrossRef]

14. Chen, X.; Yang, T.Y.; Shi, W. Influence of isolation hysteresis on the seismic performance of isolated buildings. Struct. Control Health Monit. 2015, 22, 631-647. [CrossRef]

15. Huang, B.; Zhang, H.; Wang, H.; Song, G. Passive base isolation with superelastic nitinol SMA helical springs. Smart Mater. Struct. 2014, 23, 065009. [CrossRef]

16. Fu, W.; Zhang, C.; Sun, L.; Askari, M.; Samali, B.; Chung, K.L.; Sharafi, P. Experimental investigation of a base isolation system incorporating MR dampers with the high-order single step control algorithm. Appl. Sci. 2017, 7, 344. [CrossRef]

17. Gandhi, F.; Anusonti-Inthra, P. Adaptive control of semi-active variable stiffness devices for narrow-band disturbance rejection. J. Intell. Mater. Syst. Struct. 2003, 14, 191-201. [CrossRef]

18. Yang, J.N.; Bobrow, J.; Jabbari, F.; Leavitt, J.; Cheng, C.P.; Lin, P.Y. Full-scale experimental verification of resetable semi-active stiffness dampers. Earthq. Eng. Struct. Dyn. 2010, 36, 1255-1273. [CrossRef]

19. Gavin, H.P.; Hanson, R.D.; Filisko, F.E. Electrorheological dampers, part I: Analysis and design. J. Appl. Mech. 1996, 63, 669-675. [CrossRef]

20. Noresson, V.; Ohlson, N.G.; Nilsson, M. Design of electrorheological dampers by means of finite element analysis: Theory and applications. Mater. Des. 2002, 23, 361-369. [CrossRef]

21. Lim, K.H.; Choi, S.B.; Sun, K.G.; Han, Y.M. Discrete-time fuzzy sliding mode control of vehicle suspension system featuring electrorheological damper. Smart Mater. Struct. 2015, 16, 798-808.

22. Cho, S.W.; Jung, H.J.; Lee, I.W. Smart passive system based on magnetorheological damper. Smart Mater. Struct. 2005, 14, 707-714. [CrossRef]

23. Dyke, S.J.; Spencer, B.F.J.; Sain, M.K.; Carlson, J.D. Modeling and control of magnetorheological dampers for seismic response reduction. Smart Mater. Struct. 1996, 5, 565. [CrossRef]

24. Liu, M.; Song, G.; Li, N. Non-model based semi-active vibration suppression of stay cables using Magneto-Rheological (MR) fluid damper. Smart Mater. Struct. 2007, 16, 1447-1452. [CrossRef]

25. Motra, G.B.; Mallik, W.; Chandiramani, N.K. Semi-active vibration control of connected buildings using magnetorheological dampers. J. Intell. Mater. Syst. Struct. 2011, 22, 1811-1827. [CrossRef]

26. Liu, M.; Sethi, V.; Song, G. Investigation of locking force for stay cable vibration control using magneto-rheological fluid damper. J. Vib. Acoust. Trans. ASME 2008, 130, 054504. [CrossRef]

27. Dominguez, A.; Sedaghati, R.; Stiharu, I. Semi-active vibration control of adaptive structures using magnetorheological dampers. AIAA J. 2005, 44, 1563-1571. [CrossRef]

28. Yang, G.; Spencer, B.F., Jr.; Carlson, J.D.; Sain, M.K. Large-scale MR fluid dampers: Modeling and dynamic performance considerations. Eng. Struct. 2002, 24, 309-323. [CrossRef]

29. Kwok, N.M.; Ha, Q.P.; Nguyen, M.T.; Li, J.; Samali, B. Bouc-Wen model parameter identification for a MR fluid damper using computationally efficient GA. ISA Trans. 2007, 46, 167. [CrossRef] [PubMed] 
30. Milecki, A.; Myszkowski, A.; Sędziak, D. Investigation of dynamic properties and control method influences on MR fluid dampers performance. J. Intell. Mater. Syst. Struct. 2015, 13, 453-458. [CrossRef]

31. Zhou, Y.; Li, H. Analysis of a high-rise steel structure with viscous damped outriggers. Struct. Des. Tall Spec. Build. 2014, 23, 963-979. [CrossRef]

32. Zhou, Y.; Lu, X.; Weng, D.; Zhang, R. A practical design method for reinforced concrete structures with viscous dampers. Eng. Struct. 2012, 39, 187-198. [CrossRef]

33. Jia, J.; Du, J.; Yu, W.; Hongxing, H. Design method for fluid viscous dampers. Arch. Appl. Mech. 2008, 78, 737-746.

34. Lu, X.; Zhou, Y.; Yan, F. Shaking table test and numerical analysis of RC frames with viscous wall dampers. J. Struct. Eng. 2008, 134, 64-76. [CrossRef]

35. Mcnamara, R.J.; Taylor, D.P. Fluid viscous dampers for high-rise buildings. Struct. Des. Tall Spec. Build. 2003, 12, 145-154. [CrossRef]

36. Lin, W.H.; Chopra, A.K. Earthquake response of elastic SDF systems with non-linear fluid viscous dampers. Earthq. Eng. Struct. Dyn. 2002, 31, 1623-1642. [CrossRef]

37. Mohan, D.R. Recent applications of viscoelastic damping for noise control in automobiles and commercial airplanes. J. Sound Vib. 2003, 262, 457-474.

38. Tsai, C.S.; Lee, H.H. Applications of viscoelastic dampers to high-rise buildings. J. Struct. Eng. 1993, 119, 1222-1233. [CrossRef]

39. Tsai, C.S.; Lee, H.H. Applications of viscoelastic damper to jointed structures for seismic mitigation. Eng. Mech. 1992, 408, 685-688.

40. Li, P.; Liu, S.; Lu, Z. Experimental study on the performance of polyurethane-steel sandwich structure under debris flow. Appl. Sci. 2017, 7, 1018. [CrossRef]

41. Zhang, R.H.; Soong, T.T.; Mahmoodi, P. Seismic response of steel frame structures with added viscoelastic dampers. Earthq. Eng. Struct. Dyn. 1996, 18, 389-396. [CrossRef]

42. Shukla, A.K.; Datta, T.K. Optimal use of viscoelastic dampers in building frames for seismic force. J. Struct. Eng. 1999, 125, 401-409. [CrossRef]

43. Kim, J.; Ryu, J.; Chung, L. Seismic performance of structures connected by viscoelastic dampers. Eng. Struct. 2006, 28, 183-195. [CrossRef]

44. Park, J.H.; Kim, J.; Min, K.W. Optimal design of added viscoelastic dampers and supporting braces. Earthq. Eng. Struct. Dyn. 2010, 33, 465-484. [CrossRef]

45. Kasparek, M. Glass window vibrations analysis used for positioning of piezoelectric damping elements. In Proceedings of the 2014 15th International Carpathian Control Conference (ICCC), Velke Karlovice, Czech Republic, 28-30 May 2014; pp. 223-226.

46. Lewis, T.M.; Parin, M.L. Vibration damping apparatus for windows using viscoelastic damping materials. J. Acoust. Soc. Am. 2010, 128, 3271. [CrossRef]

47. Krois, M.; Dilger, K.; Böhm, S.; Koch, S. Use of compliant adhesive layers in direct glazing of road vehicles for improved sound attenuation. Int. J. Adhes. Adhes. 2003, 23, 413-425. [CrossRef]

48. Bagaev, A.S.; Vasilieva, I.E.; Gerasimenko, V.G.; Katkow, B.G. Damping of window glass vibrations caused by speech signals circulating in the room. Telecommun. Radio Eng. 2004, 62, 903-909. [CrossRef]

49. Fan, R.; Meng, G.; Yang, J.; He, C. Experimental study of the effect of viscoelastic damping materials on noise and vibration reduction within railway vehicles. J. Sound Vib. 2009, 319, 58-76. [CrossRef]

50. Pyper, J. Laminated glass provides noise barrier benefits in automotive and architectural applications. Sound Vib. 2001, 35, 10-16.

51. Barrett, D.J. Vibration-Damping Structural Component: Acoustical Society of America. U.S. Patent 5,368,914, 29 November 1994.

52. Landin, D.T.; Gregl, B.V.; Coratti, T. Damped Glass and Plastic Laminates. U.S. Patent 2,273,371 A1, 17 October 1998.

53. Rehfeld, M.; Fournier, D.; Boure, J.P.; Payen, C. Viscoelastic Plastic Interlayer for Vibro-Acoustic Damping and Glazing Comprising such an Interlayer. U.S. Patent 20,130,316,158, 28 November 2013.

54. Kroiss, M.; Schneeweiss, H.; Muehlhofer, G.; Reichelt, M. Vibration Damping Strip for Vehicle Window. German Patent 1,980,6122A, 14 February 1999. 
55. Masayuki, S. Window Plate with Vibration Damping Member, and Vibration Damping Member. U.S. Patent 0094470, 10 November 2017.

56. Yamaguchi, T.; Kurosawa, Y.; Enomoto, H. Damped vibration analysis using finite element method with approximated modal damping for automotive double walls with a porous material. J. Sound Vib. 2009, 325, 436-450. [CrossRef]

57. Ghiringhelli, G.L.; Terraneo, M.; Vigoni, E. Improvement of structures vibro-acoustics by widespread embodiment of viscoelastic materials. Aerosp. Sci. Technol. 2013, 28, 227-241. [CrossRef]

58. Wang, J.; Xu, Y.; Zhang, W. Finite element simulation of PMMA aircraft windshield against bird strike by using a rate and temperature dependent nonlinear viscoelastic constitutive mode. Compos. Struct. 2014, 108, 21-30. [CrossRef]

59. Jones, C.J.C.; Thompson, D.J. Rolling noise generated by railway wheels with viscoelastic layers. J. Sound Vib. 2000, 231, 779-790. [CrossRef]

60. Sun, D.; Song, Y.; Zhang, X.; Zhang, L. Research on development of the viscoelastic suspensions used in construction vehicles. In Proceedings of the International Technology and Innovation Conference 2006 (ITIC 2006), Hangzou, China, 6-7 November 2006; pp. 2227-2230.

61. Zhang, R.T.; Zhao, Y.S. Damping and noise reduction technology for high Speed Trains. Foreign Rolling Stock 2005, 42, 10-17.

62. He, C.; Yuan, J.; Lin, S.; Yang, J.; Sun, X.; Meng, G. Analysis on noise inside high-speed railway passenger cars and research on control techniques of noise. J. Vib. Eng. 2004, 17, 1047-1050.

63. Sucuoğlu, H.; Girija Vallabhan, C.V. Behaviour of window glass panels during earthquake. Eng. Struct. 1997, 19, 685-694. [CrossRef]

64. Rainer, J.H. Effect of vibrations on historic buildings: An overview. Bull. Assoc. Preserv. Technol. 1982, 14, 2-10. [CrossRef]

65. Behr, R.A.; Karson, M.J.; Minor, J.E. Reliability analysis of window glass failure pressure data. Struct. Saf. 1991, 11, 43-58. [CrossRef]

66. Class, J.B.; Chu, S.G. The viscoelastic properties of rubber-resin blends. I. The effect of resin structure. J. Appl. Polym. Sci. 2003, 30, 805-814. [CrossRef]

67. Miehe, C.; Göktepe, S. A micro-macro approach to rubber-like materials. Part II: The micro-sphere model of finite rubber viscoelasticity. J. Mech. Phys. Solids 2005, 53, 2231-2258. [CrossRef]

68. Zhang, P.; Huo, L.; Song, G. Impact fatigue of viscoelastic materials subjected to pounding. Appl. Sci. 2018, 8, 117. [CrossRef]

69. Class, J.B.; Chu, S.G. The viscoelastic properties of rubber-resin blends. III. The effect of resin concentration. J. Appl. Polym. Sci. 1985, 30, 825-842. [CrossRef]

70. Wang, J.; Sun, D.; Liu, S.; Zhang, X. Damping characteristics of viscoelastic damping structure under coupled condition. Math. Comput. Appl. 2017, 22, 27. [CrossRef]

71. Guo, T.; Gu, Y.; Wang, L.; Chen, J.; Ma, S. Experimental study on dynamic mechanical properties of ZN-35 silicone rubber. J. Beijing Univ. Technol. 2016, 42, 1623-1628.

72. Zhao, Y. Properties and applications of ZN series viscoelastic damping materials. Aerosp. Mater. Technol. 2001, 2, 19-23.

73. Kong, Q.; Robert, R.H.; Silva, P.; Mo, Y.L. Cyclic crack monitoring of a reinforced concrete column under simulated pseudo-dynamic loading using piezoceramic-based smart aggregates. Appl. Sci. 2016, 6, 341. [CrossRef]

74. Yin, H.; Wang, T.; Yang, D.; Liu, S.; Shao, J.; Li, Y. A smart washer for bolt looseness monitoring based on piezoelectric active sensing method. Appl. Sci. 2016, 6, 320. [CrossRef]

75. Du, G.; Kong, Q.; Zhou, H.; Gu, H. Multiple cracks detection in pipeline using damage index matrix based on piezoceramic transducer-enabled stress wave propagation. Sensors 2017, 17, 1812. [CrossRef] [PubMed]

76. Wang, D.; Wang, Q.; Wang, H.; Zhu, H. Experimental study on damage detection in timber specimens based on an electromechanical impedance technique and RMSD-based mahalanobis distance. Sensors 2016, 16, 1765. [CrossRef] [PubMed]

77. Venugopal, V.P.; Wang, G. Modeling and analysis of Lamb wave propagation in a beam under Lead Zirconate Titanate actuation and sensing. J. Intell. Mater. Syst. Struct. 2015, 26, 1679-1698. [CrossRef] 
78. Shao, J.; Wang, T.; Yin, H.; Yang, D.; Li, Y. Bolt looseness detection based on piezoelectric impedance frequency shift. Appl. Sci. 2016, 6, 298. [CrossRef]

79. Karaiskos, G.; Flawinne, S.; Sener, J.Y.; Deraemaeker, A. Design and validation of embedded piezoelectric transducers for damage detection applications in concrete structures. Key Eng. Mater. 2013, 569, 805-811. [CrossRef]

80. Hu, Y.; Yang, Y. Wave propagation modeling of the PZT sensing region for structural health monitoring. Smart Mater. Struct. 2007, 16, 706. [CrossRef] 